\title{
M anipulação do genoma humano: ética e direito
}

\author{
M anipulation of the human genome: ethics and law
}

Maria Carolina Vaz Goulart ${ }^{1}$

FláviaGodoy Iano ${ }^{2}$

Paulo M aurício Silva ${ }^{3}$

Silvia H elena de Carvalho Sales-Peres ${ }^{4}$

Arsênio Sales-Peres ${ }^{4}$

${ }^{1}$ Faculdade de 0 dontologia deBauru, Universidade de São Paulo. Al. Octávio Pinheiro Brisola 9-75, Cidade Universitária. 17012-901 Bauru SP. mariacarolina@usp.br

${ }^{2}$ Departamento deCiências Biológicas, Área de

Bioquímica, Universidade deSão Paulo.

${ }^{3}$ M estrado em Reabilitação Oral, Faculdadede

OdontologiadeBauru,

Universidade de São Paulo.

${ }^{4}$ Departamento de

Odontopediatria,

Ortodontia eSaúde

Coletiva, Faculdadede

OdontologiadeBauru,

UniversidadedeSão Paulo.
Abstract Themolecular biology has provided the basic tool for geneticists deepening in the molecular mechanisms that influence different diseases. It should be noted the scientific and moral re sponsibility of the researchers, because the scientists should imagine the moral consequences of the commercial application of genetic tests, since thisfact involves not only theindividual and their families, but the entire population. Besides being also necessary to make a reflection on how this information from thehuman genomewill beused, for good or bad. The objective of this review was to bring the light of knowledge, data on characteristics of the ethical application of molecular biology, linking it with the rights of human beings. After studying literature, it might be observed that the H uman Genome Project has generated several possibilities, such as the identification of genes associated with diseases with synergistic properties, but sometimes modifying behavior to genetically intervene in humans, bringing benefits or social harm. The big challenge is to decide what humanity wants on this giant leap. Key words Human genome, Ethics, Law
Resumo A biologia molecular tem fornecido as ferramentas básicas para os geneti cistas se aprofundarem nos mecanismos moleculares que influem na variação das doenças. Deve-se destacar a responsabilidade científica e moral dos pesquisadores, uma vez que os cientistas devem imaginar as consequências morais da aplicação comercial detestes genéticos, já que esse fato envolvenão só 0 indivíduo e suas famílias, mas toda a população. Além de ser preciso, também, fazer uma reflexão sobre como essas informações do genoma humano serão utilizadas, para o bem ou mal. 0 objetivo desta revisão foi trazer à luz do conhecimento dados sobre características éticas da aplicação da biologia molecular, relacionando-a com os direitos do ser humano. A pósanálise bibliográfica, pôde-se observar que o Projeto Genoma Humano gerou várias possibilidades, como identificação de genes associados a doenças com propriedades sinergísticas, mas modi ficando às vezes comportamentos ao intervir geneticamente no ser humano, trazendo benefícios ou malefícios sociais. 0 grande desafio é decidir o quea humanidade pretende em relação a este gigantesco salto.

Palavras-chave Genoma humano, Ética, Direito 
Introdução

O genoma é o conjunto de toda informação de um determinado organismo, contido em seu material genético DNA (ácido desoxirribonucléico) ou mesmo RNA (ácido ribonucléico) no caso de alguns vírus. O DNA é uma macromolécula orgânica que possui a informação contida na sequência de suas bases (adenina, timina, guanina e citosina); quando necessário, essa informação é disponibilizada para a célula na forma de uma molécula deRN A mensageiro (cópia deuma pequena porção do DNA total). Essa molécula de RNA mensageiro será posteriormente lida e traduzida na forma de uma proteína, no citoplasma da célula ${ }^{1}$.

A biologia molecular tem fornecido as ferramentas básicas para os geneticistas se aprofundarem nos mecanismos moleculares e principalmentenos queinfluem na variação das doençase, com isso, a divulgação da sequência do genoma humano abriu uma nova era para a medicina².

\section{Revisão de literatura}

A "nova genética" (ou genômica) está penetrando de forma avassaladora nos mais diversos domínios do mundo contemporâneo, gerando uma revolução tecnocultural associada aos genes que tem transformado tecnologias, instituições, práticas e ideologias 3 .

Rabinow ${ }^{4}$ argumenta que a crescente impregnação da sociedade pelo conhecimento genético trará (ou já traz) mudanças em uma escala sem precedentes, jáqueanova genética deveráremode lar a sociedadeeavida com umaforça infinitamente maior que a revolução física jamais teve, porque será implantada em todo o tecido social por práticas médicas e uma série de outros discursos.

A Unesco5, que aprovou, em 1997, a Declaração Universal do Genoma Humano e dos Direitos Humanos, estabeleceu que a clonagem humana não deve ser permitida. Como este diploma não tem força de lei, o que se observa é que, pouco a pouco, os países vão flexibilizando suas posições e vários já permitem experiências para fins terapêuticos.

No Brasil, a pesquisa genética obteve assento na Constituição Federal de 1988, a qual, no Título VII - DaOrdem Social eno Capítulo VI, quetrata do meio ambiente, compreendido como "complexo de relações entreo mundo natural eosseres vivos, as quais influem na vida ecomportamento de tais seres", dispôs no art. 225, verbis: todos têm direito ao meio ambiente ecologicamente equilibrado, bem de uso comum do povo e essencial à sadia qualidade de vida, impondo-se ao Poder Público eà coletividade o dever de defendê 10 epreservá-lo para as presentes e futuras gerações.

Dispõe, ainda, no § 1 o que, para assegurar a efetividade desse direito, incumbe ao Poder Público:

a) inciso II - "preservar a diversidadeea integridade do patrimônio genético do país efiscalizar as entidades dedicadas à pesquisa e manipulação de material genético";

b) inciso V - "controlar a produção, a comercialização e o emprego de técnicas, métodos e substâncias que comportem risco para a vida, a qualidade de vida e o meio ambiente". Ademais, convém lembrar que a Carta M agna estabelece uma gama de direitos individuais e coletivos que resguardam, dentre eles, o direito à vida (artigo 5o, caput), o direito à integridade física e moral, a dignidade humana ( art. 1으, inciso III) , bem como a saúde como direito de todos e dever do Estado (artigo 196) 6 .

O genoma humano é propriedade inalienável de toda a pessoa e, por sua vez, um componentefundamental de toda a humanidade. Dessa maneira, eledeveser respeitado eprotegido como característica individual e específica, pois todas as pessoas são iguais no que se refere aos seus genes, afinal unicidadee diversidade são propriedades de grande valor da natureza humana ${ }^{7}$.

O Projeto Genoma H umano (PGH) iniciouse em 1990 para decifrar o código genético humano e sua alterações e em 2003 concluiu-se 0 sequenciamento dos três bilhões de bases do DNA da espécie humana. Os objetivos do PGH em saúde envolvem a melhoria e simplificação dos métodos de diagnóstico de doenças genéticas, otimização das terapêuticas e prevenção de doenças multifatoriais ${ }^{8}$.

Para Pena9, a problemática vai convergir na interação detrês elementos: os pesquisadores que geram o novo conhecimento, a comunidade empresarial que transforma este conhecimento em produtos ea população quevai absorver e incorporar os novos conhecimentos em sua visão de mundo e suas práticas sociais, além de consumir os novos produtos. Nesse sentido, Clotet $^{7}$ alerta para a responsabilidade científica, uma vez queos cientistas devem imaginar as consequências morais da aplicação comercial de testes genéticos.

No ser humano, será possível analisar miIhares de genes ao mesmo tempo e as informações e as tecnologias disponibilizadas têm o potencial de modificar a compreensão e os concei- 
tos atuais sobre o mecanismo de prevenção. As pessoas poderão saber se tem predisposição a determinadas doenças crônicas, como câncer, hipertensão, diabetes ou doença de Alzheimer e, desta forma, tratá-las antes do aparecimento dos sintomas. $\mathrm{Na}$ área da farmacologia, os medicamentos poderão ser administrados de acordo com o perfil genético do paciente ${ }^{10}$.

Portanto, as informações advindas do proje to devem servir para proteger a vida e melhorar a saúde. Isto pode ser verdadeiro nos casos em que há uma antecipação do processo terapêutico pela antecipação da doença; entretanto, é preciso tomar cuidado quanto aos aspectos prejudiciais deste processo ${ }^{7}$. Desde que os testes sejam voluntários e os resultados, divulgados apenas com autorização do indivíduo, respeitando assim a sua autonomia. Isso não é verdadeiro se considerarmos os testes preditivos ${ }^{11}$.

Mas, pensando por outro lado, acredita-se que tomamos um caminho perigoso: ao invés de julgar um indivíduo pelo que ele éhoje, vamos indagar sobre seu status de doente em potencial (e quem não é?) para tratá-lo como deficiente antes do tempo e sem ter a certeza de que se tornará12. Para ele, isso significa definir a afecção pelo genótipo, pelo que está inscrito no DNA e não mais pelo fenótipo, pelo estado presente da pessoa. Várias discussões no congresso já foram travadas por esse motivo. Com isso, foram estabelecidas algumas normas eleis, como a vigente Lei $n$ 8.974/95 (lei de biossegurança) que, concretizando o texto constitucional, estabelece normas para o uso de técnicas de engenharia genética eliberação no meio ambiente de organismos geneticamente modificados (OGM) e, expressamente, veda a manipulação genética de células germinais humanas, bem como autoriza o Poder Executivo a criar, no âmbito da Presidência da República, a Comissão Técnica Nacional de Biossegurança.

Assim, logo em seu artigo 1o , essa importantelegislação, dispõe: Art. 10 Esta lei estabelecenormas de segurança e mecanismos de fiscalização no uso das técnicas de engenharia genética na construção, cultivo, manipulação, transporte, comercialização, consumo, liberação e descarte de organismo geneticamente modificado (OGM), visando a proteger a vida ea saúde do homem, dos animais e das plantas, bem como o meio ambiente ${ }^{13}$.

Também, existe uma preocupação quanto à divulgação das informações genéticas, caso possa interferir com a privacidade das pessoas, podendo eventualmente prejudicá-las ${ }^{14}$.

0 acesso e a divulgação dos dados genéticos, deformaindevida, ofendem a intimidadeda pes- soa, colocando em risco sua autonomia, parte integrante da personalidade, impede ou dificulta o acesso ao trabalho e à contratação de seguro particular de saúde e de vida, apresentando risco de estigmatização e discriminação social ${ }^{15}$.

Em síntese, a rel ação dicotômica liberdadede investigação versus limites à investigação retrata a tensão entre direitos fundamentais. Deum lado, o exercício de um direito que, ao resguardar a capacidade criativa do homem, assegura o progresso da ciência, voltado ao bem-estar individual esocial, direito esseque pressupõe a experimentação com seres humanos, sem a qual a medicina não poderia avançar na luta contra enfermidades e na busca do alívio do sofrimento. De outro, os direitos à vida eà integridade corporal, bem como o respeito à dignidade humana, que podem ser violados no trabalho de investigação ou experimentação ${ }^{16}$.

O conhecimento das características genéticas humanas pode ensejar discriminação, quando aliado ao poder do homem de interferir na constituição genética dos seres humanos, e poderá conduzir à prática criminosa de "limpeza étnica", gerando, com isso, uma discussão de até que ponto éético a utilização dessas informações genômicas. Esta revisão de literatura objetivou relacionar estudos científicos que ponderam sobre o direito e características éticas da aplicação do conhecimento da biologia molecular.

\section{Discussão}

A identificação dos genes que respondem pelas características normais e patológicas de todo ser vivo será no futuro próximo o fator responsável pelo mapeamento do código genético. Com 0 conhecimento deste patrimônio, o homem poderá formar um banco de dados que permitirá 0 controle sobre os genes e suas mutações, podendo introduzir materiais produzidos pela tecnobiociências quando alguma condição adversa se impuser ${ }^{17}$.

Em relação à autonomia, Wiesenthal e Wiener ${ }^{18}$ ressaltam que as pessoas poderão não ser capazes de manter a privacidade de seus direitos face ao grande incentivo dado para o conhecimento do genoma individual. Nestesentido, existe grande preocupação com a possibilidade de discriminação com baseno conhecimento do genótipo individual. Situações concretas seriam 0 acesso aos planos de assistência privada de saúde, a seleção para postos de trabalho, seleção para ingresso em instituições de ensino, além da opor- 
tunidadena aquisição de empréstimos. Por exemplo, é razoável que seguradoras solicitem testes genéticos para determinar el egibilidade para cobertura de seus segurados? Assegurar saúde a todo custo poderequerer a proposta de um abortamento, caso esses testes indiquem que $0 \mathrm{em}$ brião poderá ser acometido por alguma doença genética? Caso mantida a gestação, as seguradoras e os promotores de saúde estão autorizados a recusar cobertura para este indivíduo?

Por outro lado, Beckman ${ }^{19}$ contrapõe que a autonomia individual não ér reduzida ou aniquilada pelas informações genéticas, mas pelas interpretações errôneas e mal-entendidos oriundos dos resultados destes testes. Para evitar isso, políticas de mercado quanto ao uso e utilidade dosmesmos devem ser ainda mais rigorosamente estudadas.

Várias descobertas relacionadas com a decodificação de alguns genes já estão sendo usadas em diversas áreas do conhecimento.

$\mathrm{Na}$ saúde, por exemplo, um número crescentedeestudos na área de doen ças psiquiátricas mostra a influência genética em distúrbios de comportamento. Descobriu-se, por exemplo, um polimorfismo ligado ao gene transportador da serotonina quecausa uma recaptação diminuída dessa substância na fenda sináptica. Pacientes com doença de Alzheimer e distúrbios psiquiátricos (depressão maior, disritmia e doença bipolar) diferem quanto a esse polimorfismo em comparação com controles normais. Em um estudo muito interessante, realizado na N oruega, verificou-seque, entre os alcoólatras, aqueles que se tornam agressivos sob o efeito do álcool também diferem dos não agressivos em relação a esse polimorfismo ${ }^{20}$.

O Projeto Genoma Humano gerou várias expectativas, dentre elas, a possibilidade de rastrear genes associados a doenças e comportamentose, mais ainda, de intervir geneticamente no ser humano, trazendo benefícios sociais. Contudo, haja vista a novidade, complexidade e amplitude do assunto, é natural que existam opiniões discordantes e questões ainda abertas, com relação a como isto deve ocorrer. Portanto, por um lado deve-se evitar o radicalismo intransigente, mas, por outro lado, também são inaceitáveis as flexibilizações motivadas por interesses pessoais ou grupais ${ }^{14}$. Tudo deve ser feito a favor da pessoa, respeitando principalmente a sua autonomia.

Neste ínterim, permanecem as questões de saber quais são direitos do homem de usufruir dessa era genômica e quais os limites éticos para não haver abuso na aplicação desta nova tecnologia. N esse tempo avassalador do progresso científico, há o perigo da pulverização do objetivo da ciência genômica, que é o bem-estar da humanidade e o crescimento do grau de desempenho científico, em que antes valem a utilidade e eficiência da descoberta do que a verdade sobre as leis intrínsecas do fenômeno ${ }^{21}$.

\section{Conclusão}

Portanto, é preciso fazer uma reflexão sobre como essas informações do genoma humano serão utilizadas. Se para um melhor aprimoramento da medicina e, com isso, uma melhora no diagnóstico e tratamento da população ou se essas informações serão usadas como uma forma dediscriminação da população em geral, podendo até provocar uma nova eugenia.

0 grande desafio é decidir o que a humanidade pretende em relação a este gigantesco salto que, se por um lado acena com possibilidades terapêuticas inimagináveis, por outro exibe um terrível potencial de desestruturação social, provocando mudanças extraordinárias em sua organização e possibilitando a ação de verdadeiros marginais da ciência, que poderão criar legiões de seres humanos com os mais diversos objetivos, nem todos dignos. 


\section{Colaboradores}

MCV Goulart trabalhou na elaboração, correções, editoração elevantamento bibliográfico. FG Iano ePM Silva trabalharam na elaboração e levantamento bibliográfico. SHC Sales-Peres e A Sales-Peres trabalharam na concepção, orientação e revisão final.

\section{Referências}

1. Nelson DL, Cox MX. Leningher. Princípios de Bioquímica. 3a ed. São Paulo: Sarvier; 2002.

2. Venter JC et al. The sequence of the human genome. Science 2001; 291:1304-1351.

3. Santos RV, M aio M C. Qual "retrato do Brasil"? Raça, biologia, identidades e política na era da genômica. M ana 2004; 10(1):61-95.

4. Rabinow P. Artificiality and enlightenment: from sociobiology to biosociality. In: Crary J, Kwinter S editors. Incorporations. New York: Zone Books; 1992. p. 234-252.

5. Unesco. Universal declaration on the human genome and human rights. Rev Der Gen H 1998; 9:119141.

6. Farias PJ. A manipulação do patrimônio genético no contexto do ordenamento jurídico vigente. [site da Internet] [acessado $2007 \mathrm{dez}$ 15]; [cerca de 4 p.]. Disponível em: http://http://jus2.uol.com.br/doutrina/texto. asp?id=1848

7. Clotet J. Bioética como ética aplicada e genética. Bioética 1997; 5(2):173-183.

8. Floria-Santos M, Nascimento LC. Perspectivas historicas del Proyecto Genoma y la evolución de la enfermería. Rev. bras. enferm. 2006; 59(3):358-361.

9. Pena SDJ. First South-N orth Human Genome Conference. Gene 1992; 120:327-328.

10. Gattás GJF, Segre M, W ünsch Filho V. Genética, biologia molecular e ética: as relações trabalho e saúde. Cien Saude Colet 2002; 7(1):159-167.

11. Wells RJ, Biesecker LG, Wilfond BS, Elias S, Annas GJ. Generic Consent for Genetic Screening. NEJM 1994; 331:1024-1025.

12. Collins FS, Patrinos A, Jordan E, Chakravarti A, Gesteland R, Walters L. New Goals for the U.S H uman Genome Project: 1998-2003. Science 1998; 282(5389):682-689.

13. Brasil. Lei $n^{\circ} 8.974$ (Lei de Biossegurança) de 5 de janeiro de 1995. Estabelece normas para o uso de técnicas de Engenharia Genética e liberação no meio ambiente de organismos geneticamente modificados (OGM) e, expressamente, veda a manipulação genética de células germinais humanas, bem como autoriza o Poder Executivo a criar, no âmbito da Presidência da República, a Comissão Técnica Nacional de Biossegurança. Diário O ficial da União 1991; 5 jan.
14. Bandeira FM GC, Gomes YM, Abath FGC. Public health and ethics in the age of genomic medicine: genetic screening. Rev. Bras. Saude M ater. Infant. 2006; 6(1):141-146.

15. Cavoukian A. La confidencialidad en la genética: la necesidad del derecho a la intimidad y el derecho a "no saber". Rev Derecho y Genoma Humano1995; 2:55-69.

16. Peluso LTP. A revolução biológica e os direitos humanos [dissertação]. São Paulo (SP): Faculdade de Direito, Universidade de São Paulo; 2001.

17. Cardoso MHC, Castiel L. Saúde coletiva, nova genética e a eugenia de mercado. Cad Saude Publica 2003; 19(2):653-662.

18. Wiesenthal DL, Wiener NI. Privacy and the human genome project. Ethics Behav. 1997; 6(3):189-201.

19. Beckman L. Are genetic self-tests dangerous? Assessing the commercialization of genetic testing in terms of personal autonomy. Theor M ed Bioeth. 2004; 25(5-6):387-398.

20. Zatz M. Projeto genoma humano e ética. São Paulo em Perspectiva 2000; 14(3):47-52.

21. Azevedo DT. Breve reflexão sobre os aspectos éticos e jurídicos do projeto genoma humano. Boletim do Inst M anoel Pedro Pimentel 2001; 2(16):17-24.
Artigo apresentado em 01/11/2007 Aprovado em 05/12/2007 